DOI: 10.24326/fmpmsa.2017.4

\title{
DETERMINATION OF VOLATILE COMPOUND IN FERMENTED CAMEL MILK BY GC-MS
}

\author{
Hussein L. AL-GBOORY \\ University Al- Qasim Green, Babylon, IRAQ \\ E-mail of corresponding author: hblcf@yahoo.com
}

Keywords: Fermented Camel Milk, volatile compounds, Lactic acid bacteria

\begin{abstract}
Camel milk is important in sustainable development and in ensuring the nutritional needs of future generations. Thus, this study focuses on camel milk products. Volatile compounds were investigated for fresh camel milk and fermented camel milk using a mixture of the starter bacteria formed of Lactobacillus delbrueckii subsp. bulgaricus and Streptococcus thermophilus. The results showed difference in quality of volatile compounds in fresh camel milk from those found in fermented camel milk, with the presence of compounds such as -:9,12,15 Octa- decatrienoic acid, 2-[(trimethylsilyl) oxy]- 1- [( trimethylsilyl ) oxy] methyl] ethyl ester, (Z,Z,Z), cis-13 Eicosenoi cac id, pyridazine2,7- Diphenyl -1,6dioxopyr idazino [4,5:2',3'] pyrrolo[4',5'-d] ,Octa-decanoic acid,4-hydroxy-, methyl ester, Stearic acid, 3(octadecyloxy) propyl ester, 1,2-Propanediol, diacetate, Glycine, N-[(3à,5á,7à,12à)-24-oxo-3,7,12-tris [(trimethylsilyl)oxy]cholan-24-yl]-, methyl ester, ethyl allocholate iso1.82, Octasiloxane hexadecamethyl. In fresh camel milk either the compounds that were diagnosed in fermented camel milk were included on, such as tert- Hexadecanethiol, glycerin Desulphosinigrin. The results indicated that many volatile compounds were found in fresh and fermented camel milk, with a clear difference in quality and concentration. In conclusion, the use of the starter bacteria produced an obvious change in the flavor of fermented camel milk.
\end{abstract}

\section{INTRODUCTION}

Number of camels in Iraq increased in the period 1995-2014 from 5,400 to 62,000 camel heads (FAO, 2014). Production of camel milk is one of the most important goals to achieve food and agricultural interdependence in Iraq. Moreover, camel milk substantially contributes in the sustainable development through camel milk products and dairy products. One of these products is fermented camel milk. The fermentation process is one of the most important food industry methods, especially in the field of food preservation technology. It results in desired changes in food making it more popular in terms of taste, and it has a role in preventing the growth of pathogenic microorganisms (Mufandaedza et. al., 2006; Mosha\& Vicent, 2004).

Naturally fermented camel milk forms a large part of the diet in the desert and semi-desert regions of East Africa (Farah et. al., 1990). It is also used in the manufacture of a number of dairy products such as fermented milk, yoghurt (Elayan et. al., 2008) (Hashim et. al., 2008). Furthermore, it has a medical importance as an antidote to many infectious diseases, cancers, and diabetes. On the other hand, camel's milk maybe suitable for drinking and the remainder of it, is used to feed young camels (Yagil et. al., 1984) or may be converted into fermented milk by leaving milk for several hours in pottery or leather containers (Yagil and Etzion, 1980; Ramet, 2001). One of the products of fermented milk is Suusac. It is natural yeast as it is made during self-fermentation and under room temperature for one to two days (Lore et. al., 2005). In general, lactic acid bacteria (LAB), which is a substance that is added to food, is generally recognized as safe (GRAS) for human consumption (Aguirre \& Collins, 1993). 
Some of the plant or microbial extracts have been found to be highly effective as antimicrobial, anti-inflammatory, anti-oxidant, anti-cholesterol, anticancer, liver protection, anti-inflammatory, anti-histamine. The reason is that these extracts contain natural flavonoids, (Hexadecaonoic acid, ethyl ester and n- Hexadecaonoic acid) as well as containing unsaturated fatty acids and docosatetraenoic acid and octadecatrienoic acid (Kumar et. al., 2010).

Volatile compounds are often used as an indicator of milk quality. Many studies have indicated that the estimation of these compounds gives an impression on the conditions of storage and storage temperature (Urbach, 1990). Thus, in countries with abundant of camel milk the focus has been on studying its composition. In Egypt, El-Agamy (1983) found that camel milk contained $3.7 \%$ protein, $2.9 \%$ fat, $5.8 \%$ lactose, and ash $0.7 \%$. The changes to the flavor of milk and its products are the result of the metabolic effects of micro-organisms where secondary metabolites are introduced during the growth phase (Urbach \& Milne 1987). Therefore, the aim of this study is to determine the flavor compounds found in fresh camel milk and estimated in fermented camel milk and changes during fermentation.

\section{MATERIAL AND METHODS}

Camel milk samples:

Camel milk samples were collected from central and western Iraq and transferred in sterile and cold conditions to the lab for further processing.

Culture growth and maintenance:

Yogurt starter (Streptococcus thermophilus and Lactobacillus delbrueckii sp. bulgaricus) was obtained from Danisco, Denmark and was used to inoculate skim milk at $42^{\circ} \mathrm{C}$, after being incubated for $24 \mathrm{~h}$ and cooled after fermentation to $4^{\circ} \mathrm{C}$ for short time use.

\section{Preparation of fermented camel milk:}

The fermentation process was prepared as described by Rahman et al. (2009). The skim camel milk was pasteurized for $30 \mathrm{~min}$ in a water bath in $500 \mathrm{ml}$ screwed bottles at $90 \mathrm{C}$ and cooled immediately to $5 \pm 1 \mathrm{C}$ in an ice bath. The milk samples $(500 \mathrm{ml})$ were equilibrated for one hour at the fermentation temperature $\left(42^{\circ} \mathrm{C}\right)$ in a water bath before inoculation with the starter cultures. Each sample was inoculated with $5 \%\left(10^{6}-10^{7} \mathrm{cfu} / \mathrm{ml}\right)$ of mixed yogurt culture (S. thermophilus and Lactobacillus delbrueckii sp. bulgaricus) at a ratio of $1: 1$. Samples were thoroughly mixed after inoculation and incubated at $42^{\circ} \mathrm{C}$ for $6 \mathrm{~h}$.

\section{Water-Soluble Extracts (WSE):}

The water-soluble extracts (WSEs) of fresh camel milk and fermented camel milk samples were prepared as described by Kuchroo and Fox (1982).

Extraction and determination of volatile compounds:

The extraction of the volatile compounds in fresh camel milk and fermented camel milk were performed as recommended by the liquid/liquid or liquid/solid extraction (direct extraction techniques) method (Mariaca and Bosset, 1997; Preininger et. al., 1994). This protocol was taken place through acetonitrile solvent for low-fat dairy products. Volatiles 
flavored compounds were identified on Gas chromatography -Mass Spectrometry (GCMS) according to Agilent company's instruction manual and according to the following conditions: Column (ZEBRON ZB-FFAP 30meter x $0.25 \mathrm{~mm}$ I.D x $0.25 \mu \mathrm{m}$ ). The operating conditions of the device are: sampling time: $1.00 \mathrm{~min}$ 'Inj. Initial temp.:250.00.C, Interface temp: $260.00^{\circ} \mathrm{C}$, Column Inlet Pressure: $56.7 \mathrm{kpa}$, Total flow: $23.0 \mathrm{ml} / \mathrm{min}$. The oven temperature was $70^{\circ} \mathrm{C} / 3 \mathrm{~min}$ and the temperature is $260{ }^{\circ} \mathrm{C} / 20 \mathrm{~min}$ and the pressure inside the column is $56.7 \mathrm{Kpa} / 3 \mathrm{~min}$ and the pressure is $185.9 \mathrm{Kpa} / 20 \mathrm{~min}$.

\section{RESULTS AND DISCUSSION}

Volatile compounds, identified in fresh camel milk by using Gas chromatography - Mass Spectrometry (GC/MS), are listed in Table 1 . Figure 1 shows $\{9,12,15-$

Octadecatrienoic acid, 2[(trimethylsilyl)oxy]1[(trimethylsilyl) oxy]methyl] ethyl

ester,(Z,Z,Z)1.78\%.cis-13-Eicosenoic acid.17\% pyridazine2,7-Diphenyl1,6 dioxopyr idazino.[4,5:2',3'].Pyrrol.[4',5'-d]pyridazin 2.10\% Octadecanoic acid, 4hydroxy, methyl.ester.2.02\%,.Stearicacid 3-(octade-cyloxy) propyl ester 3.67\% 1,2Propane-diol 3, diacetate.6.59\% Glycine, N[(3à,5á,7à,12à)-24-oxo 3,7,12-tris [(trimethylsilyl)oxy]cholan-24-yl]-, methyl ester $13.24 \%$ Ethyl isoallo.cholate $1.82 \%$

Octasiloxane hexadecamethyl $30.76 \%$.

The results showed that there is a mixture of volatile flavor compounds and active and bioactive compounds that can be detected using GC-MS as this device has the ability to diagnose long chain hydrocarbons, alcohols, acids, esters, alkaloids, steroids, and amino and nitrogen compounds (Venkatesh et. al., 2014). The process of compounds diagnosis is based on the calculation of retention time (RT), molecular formula, molecular weight, and concentration (Peak area \%). Some of the substances that have been diagnosed as volatile compounds have significant efficacy and the importance as antimicrobial agents, as it found that the substance Glycine,N-[(3à,5á,7à,12à)-24-oxo-3,7,12-tris [(trimethylsilyl)oxy] cholan-24-yl]-,ester methyl is important as an anti-bacterialgrowth (Ganesh \&Vennil 2011).

The volatile compounds that have been diagnosed in raw milk using solid phase microextraction and by using the GC/MS device are belong to different types, which include compounds in the form of aldehydes chains like hexanal, heptanal, octanal, nonanal, or methyl ketones (2-heptanone and 2-nona- none) or ketones (3-octen-2-one and 3,5octadien-2-one). However, volatile flavored compounds can be used as a guide and indicator of the oxidizing taste of milk as in the case of the use of aldehydes and ketone compounds ( $\mathrm{Li}$ et. al. 2012).It deserves to note that the materials responsible for flavor dairy products include a large number of volatile compounds (Molimard \& Spinnler, 1996; Urbach, 1997). These compounds may include large amounts of free carboxylic acids, sulfur compounds and substances containing alkali nitrogen such as amines and pyridines and many neutral compounds such as carbonyl (met-hyl ketones), aldehydes, primary and secondary alcohol, esters, ketones, ethers, aliphatic and aromatic hydrocarbons (Dafflon et. al.,1995). 
Table 1. Volatile compounds as analyzed by GC-MS in Fresh camel milk

\begin{tabular}{|l|c|c|c|c|}
\hline \multicolumn{1}{|c|}{ Compound Name } & RT & $\begin{array}{c}\text { Molecular } \\
\text { Weight }\end{array}$ & $\begin{array}{c}\text { Molecular } \\
\text { Formula }\end{array}$ & Area \% \\
\hline $\begin{array}{l}\text { 9,12,15-Octadecatrienoic acid, 2[(trimethylsilyl)oxy]-1- } \\
\text { [[( trimethylsilyl)oxy]methyl]ethyl ester, (Z,Z,Z) }\end{array}$ & 3.81 & 496 & C27H52O4Si2 & 1.78 \\
\hline cis-13-Eicosenoic acid & 4.52 & 268 & $\mathrm{C} 16 \mathrm{H} 28 \mathrm{O} 3$ & 2.14 \\
\hline $\begin{array}{l}\text { pyridazine2,7-Diphenyl-1,6-dioxopyr } \\
\text { idazino[4,5:2',3']pyrrolo[4', 5'-d]pyridazine }\end{array}$ & 6.19 & 355 & $\mathrm{C} 20 \mathrm{H} 13 \mathrm{~N} 5 \mathrm{O} 2$ & 2.10 \\
\hline Octadecanoic acid,4-hydroxy-, methyl ester & 7.12 & 314 & $\mathrm{C} 19 \mathrm{H} 38 \mathrm{O} 3$ & 2.02 \\
\hline Stearic acid,3-(octadecyloxy)propyl ester & 7.38 & 394 & $\mathrm{C} 39 \mathrm{H} 78 \mathrm{O} 3$ & 3.67 \\
\hline 1,2- Propanediol, 3-(hexadecyloxy)-,diacetate & 9.54 & 400 & $\mathrm{C} 23 \mathrm{H} 44 \mathrm{O} 5$ & 6.59 \\
\hline Ergosta-5,22-dien-3-ol, acetate, (3á,22E)- & 9.87 & 440 & $\mathrm{C} 30 \mathrm{H} 48 \mathrm{O} 2$ & 11.54 \\
\hline $\begin{array}{l}\text { Glycine, N-[(3à,5á,7à,12à)-24-oxo-3,7,12- } \\
\text { tris[(trimethylsilyl)o xy]cholan-24-yl]-, methyl ester }\end{array}$ & 11.16 & 695 & $\mathrm{C} 36 \mathrm{H} 69 \mathrm{NO6Si3}$ & 13.24 \\
\hline Ethyl iso-allocholate & 15.92 & 436 & $\mathrm{C} 26 \mathrm{H} 44 \mathrm{O} 5$ & 1.82 \\
\hline Octasiloxane hexadecamethyl & 22.31 & 578 & $\mathrm{C} 16 \mathrm{H} 50 \mathrm{O} 7 \mathrm{Si} 8$ & 30.76 \\
\hline
\end{tabular}

Table 2. Volatile compounds as analyzed by GC-MS in fermented camel milk

\begin{tabular}{|c|c|c|c|c|}
\hline Compound Name & RT & $\begin{array}{l}\text { Molecular } \\
\text { Weight }\end{array}$ & $\begin{array}{l}\text { Molecular } \\
\text { Formula }\end{array}$ & Area \% \\
\hline tert- Hexadecanethiol & 4.38 & 258 & $\mathrm{C} 16 \mathrm{H} 34 \mathrm{~S}$ & 7.60 \\
\hline Glycerin & 8.42 & 92 & $\mathrm{C} 3 \mathrm{H} 8 \mathrm{O} 3$ & 82.76 \\
\hline Desulphosinigrin & 9.97 & 279 & C10 H17 NO6S & 9.64 \\
\hline $\begin{array}{l}\text { 4-Piperidineacetic acid, 1-acetyl-5-ethyl-2-[3-(2- } \\
\text { hydroxyethyl)-1H-indol-2-yl]-à -methyl-, methyl ester }\end{array}$ & 13.81 & 400 & $\mathrm{C} 23 \mathrm{H} 32 \mathrm{~N} 2 \mathrm{O} 4$ & 3.81 \\
\hline $\begin{array}{l}\text { Octasiloxane, } 1,1,3,3,5,5,7,7,9,9,11,11,1 \\
\text { 3,13,15,15-hexadecamethy } 1 \text { - }\end{array}$ & 22.17 & 578 & C16H50O7Si8 & 3.97 \\
\hline $\begin{array}{l}\text { Hexasiloxane, } 1,1,3,3,5,5,7,7,9,9,11,11- \\
\text { dodecamethyl- }\end{array}$ & 22.54 & 430 & C12H38O5Si6 & 5.06 \\
\hline $\begin{array}{l}\text { Heptasiloxane, } 1,1,3,3,5,5,7,7,9,9,11,11,1 \\
\text { 3,13-tetradecamethyl- }\end{array}$ & 22.74 & 504 & C14H44O6Si7 & 5.69 \\
\hline
\end{tabular}

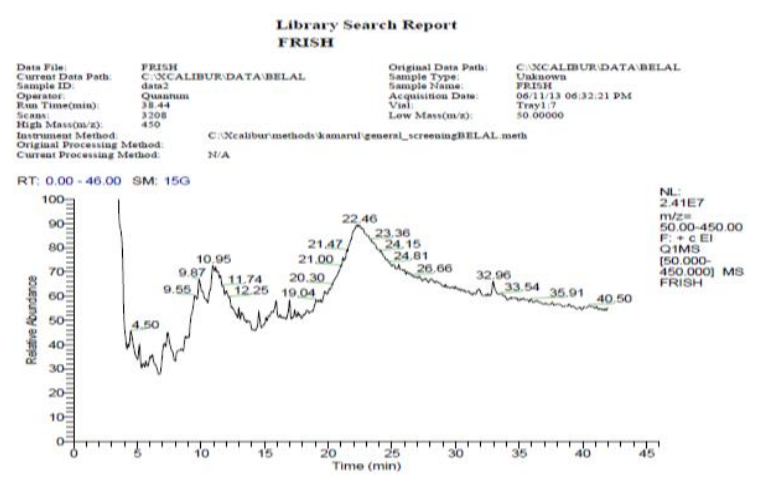

Fig.1.GC-MS analysis of Volatile compounds in Fresh camel milk

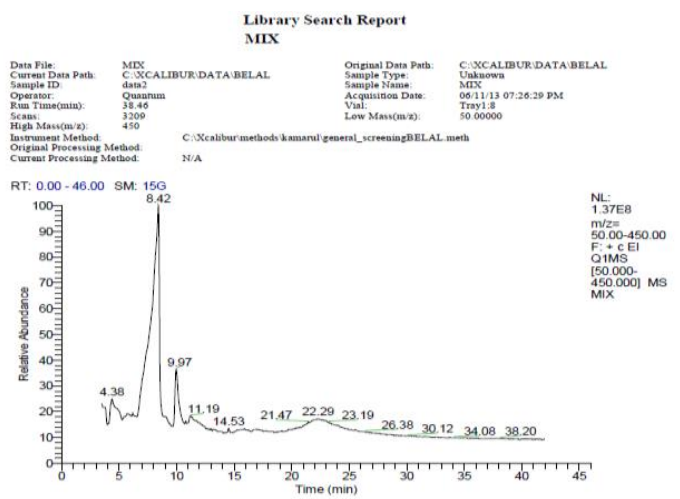

Fig.2.GC-MS analysis of Volatile compounds in Fermented camel milk

Moreover, more than 100 volatile substances, including carbonyl compounds, alcohol, acids, esters, hydrocarbons, aromatic compounds, sulfur-containing compounds, and heterogeneous ring compounds, were found in fermented milk at a low or very low concentration (Cheng, 2010). Finally, the present study showed that the process of fermentation of camel's milk by lactic acid bacteria plays an important role in the flavor of 
fermented milk, while the production of most flavor compounds in milk was found to be the degradation of milk fat and microbiological shifts of lactose and citrate.

\section{CONCLUSION}

In this study, the volatile components of fresh camel milk and fermented camel milk (Lactobacillus delbrueckii subsp. bulgaricus and Streptococcus thermophilus) were analyzed by GC MS. Volatile compounds were identified. It was also identified that the major volatile components were alcohols and fatty acids, which played the most important role in imparting the typical aroma and flavor. The results indicated that there were many volatile compounds in fresh and fermented camel milk, with a clear difference in quality and concentration. This study showed that fermentation of camel milk by lactic acid bacteria plays an important role in fermented milk flavor. The use of the starter bacteria produced an obvious change in the flavor of fermented camel milk. There is still a lot of work to be done to get a more complete understanding of the formation of aroma and flavor of milk. Determining the relationship between the main aromatic compounds and the sensory properties of fermented camel milk can provide a better understanding of how milk flavor is affected by the presence of flavor compounds to make it more acceptable to the consumer.

\section{ACKNOWLEDGMENT}

A lot of thanks to the staff of the laboratories of the Faculty of Food Science and Technology at University of Putra of Malaysia to assist in the analysis of samples.

\section{REFERENCES}

Aguirre, M., \& Collins, M. D. (1993). Lactic acid bacteria and human clinical infection. Journal of Applied Microbiology, 75(2), 95-107.

Cheng, H. (2010). Volatile flavor compounds in yogurt: a review. Critical reviews in food science and nutrition, 50(10), 938-950.

Dafflon, O., Gobet, H., Koch, H., \& Bosset, J. O. (1995). Le dosage des hydrocarbures aromatiques polycycliques dans le poisson, les produits carnés et le fromage par chromatographie liquide à haute performance. Mitteilungen aus dem Gebiete der Lebensmitteluntersuchung und Hygiene, 86(5), 534-555.

El-Agamy, E. I. (1983). Studies on camel's milk. Alexandria University, Egypt: MSc Thesis.

Elayan, A. A., Suleiman, A. M. E., \& Saleh, F. A. (2010). The Hypocholesterolemic Effect of Gariss and Gariss Containing. Asian Journal of Biochemistry, 5(3), 205-209.

FAO (2014). Food and Agriculture Organization. http://www.fao.org/faostat/en/\#data/QA

Farah, Z., Streiff, T., \& Bachmann, M. R. (1990). Preparation and consumer acceptability tests of fermented camel milk in Kenya. Journal of Dairy Research, 57(2), 281-283.

Ganesh, S., \& Jannet Vennila, J. (2011). Photochemical Analysis of Acanthus ilicifolius and Avicennia officinalis by GC-MS. Research Journal of Photochemistry, 5(1), 60-65.

Hashim, I. B., Khalil, A. H., \& Habib, H. (2009). Quality and acceptability of a set-type yogurt made from camel milk. Journal of dairy science, 92(3), 857-862.

Jegadeeswari, P., Nishanthini, A., Muthukumarasamy, S., \& Mohan, V. R. (2012). GC-MS analysis of bioactive components of Aristolochia krysagathra (Aristolochiaceae). Journal of current chemical and pharmaceutical sciences, 2(4). 
Kuchroo, C. N., \& Fox, P. F. (1982). Soluble nitrogen in Cheddar cheese: comparison of extraction procedures. Milchwissenschaft, 37, 331-335

Kumar, P. P., Kumaravel, S., \& Lalitha, C. (2010). Screening of antioxidant activity, total phenolics and GCMS study of Vitex negundo. African Journal of Biochemistry Research, 4(7), 191-195.

Li, Y., Zhang, L., \& Wang, W. (2012). Formation of aldehydes and ketone compounds during production and storage of milk powder. Molecules, 17(8), 9900-9911.

Lore, T. A., Mbugua, S. K., \& Wangoh, J. (2005). Enumeration and identification of microflora in suusac, a Kenyan traditional fermented camel milk product. LWT-Food Science and Technology, 38(2), 125-130.

Molimard, P., \& Spinnler, H. E. (1996). Compounds involved in the flavor of surface mold-ripened cheeses: origins and properties. Journal of dairy science, 79(2), 169-184.

Mosha, T. C. \& Vicent, M. M. (2004). Nutritional value and acceptability of homemade maize/sorghumbased weaning mixtures supplemented with rojo bean flour, ground sardines and peanut paste. International journal of food sciences and nutrition, 55(4), 301-315.

Mufandaedza, J., Viljoen, B. C., Feresu, S. B., \& Gadaga, T. H. (2006). Antimicrobial properties of lactic acid bacteria and yeast-LAB cultures isolated from traditional fermented milk against pathogenic Escherichia coli and Salmonella enteritidis strains. International journal of food microbiology, 108(1), 147-152.

Preininger, M., Rychlik, M., \& Grosch, W. (1994). Potent odorants of the neutral volatile fraction of Swiss cheese (Emmentaler). Developments in food science.

Rahman, I. E. A., Dirar, H. A., \& Osman, M. A. (2009). Microbiological and biochemical changes and sensory evaluation of camel milk fermented by selected bacterial starter cultures. African Journal of Food Science, 3 (12), 398-405.

Ramet, J. P. (2001). The technology of making cheese from camel milk (Camelus dromedarius) (No. 113). Food \& Agriculture Org.

Urbach, G. (1990). Headspace volatiles from cold-stored raw milk. Australian Journal of Dairy Technology. $45(2), 80-85$

Urbach, G. (1997). The chemical and biochemical basis of cheese and milk aroma. In: Microbiology and biochemistry of cheese and fermented milk (pp. 253-298). Springer US.

Urbach, G., \& Milne, T. (1987). The concentration of volatiles in pasteurized milk as a function of storage time and storage temperature-a possible indicator of keeping quality. Australian Journal of Dairy Technology,42, 53-8

Venkatesh, R., Vidya, R., \& Kalaivani, K. (2014). Gas Chromatography and Mass Spectrometry analysis of Solanum Villosum (Mill)(Solanaceae). International Journal of Pharmaceutical Sciences and Research, 5(12), 5283.

Yagil, R. and Etzion, Z. (1980). Effect of drought condition on the quality of camel milk. Journal Dairy Research, 47:159-166.

Yagil, R., Saran, A., \& Etzion, Z. (1984). Camels' milk: for drinking only? Comparative Biochemistry and Physiology Part A: Physiology, 78(2), 263-266. 